\title{
PECULIARITIES OF THE USAGE \\ OF INTERACTIVE TECHNOLOGIES IN THE PROCESS \\ OF PROFESSIONAL TRAINING OF THE FUTURE SPECIALISTS \\ OF CULTURAL-AND-LEISURE SPHERE
}

\section{Kalinina Larysa ${ }^{1}$ \\ Orlova Olena ${ }^{2}$}

DOI: http://dx.doi.org/10.30525/978-9934-571-27-5_19

\begin{abstract}
The problems of high quality training of future workers for cultural-and-leisure sphere are considered to be up-to-date these days. That is a characteristic feature of nowadays and is one of the most important trends of domestic education modernization, a significant factor of providing the educational demands. Recently, in Ukraine the tendency of wide introduction of interactive methods and training technologies is observed. At present, the problem of development and introduction of innovative pedagogical technologies into educational process of the higher educational institution is studied both in theoretical and didactic aspects, moreover, the foreign experience as for introduction of pedagogical innovations is actively investigated. Appearance, development and introduction of interactive methods into the higher education system are stipulated by the fact that modern education faces new tasks: not only to give students knowledge but provide them with formation and development of their cognitive activities and abilities, creative thinking, independent thinking work skills.
\end{abstract}

\section{Introduction}

The educational reforms in Ukraine are being caused by political, economic and social transformations and result in the necessity of its improving and approaching the levels of the world educational standards.

The strategic tasks of building up the educational system require solving out of a number of scientific and practical problems closely connected with

${ }^{1}$ Candidate of Pedagogical Sciences,

Senior Lecture at the Department of Culturology,

Separate Division "Mykolaiv Branch of Kyiv National University of Culture and Arts", Ukraine

${ }^{2}$ Candidate of Culturology,

Senior Lecture at the Department of Culturology,

Separate Division "Mykolaiv Branch of Kyiv National University of Culture and Arts", Ukraine 
the professional training and advancing the qualification of the workers engaged in the cultural-and-leisure sphere.

The problems of the qualitative training of the future workers of the cultural-and-leisure sphere are to be up-to-date these days. The optimization of this process is raveled with specific peculiarities of an adult [4, p. 273] and requires the use of new forms and methods those could ensure effective developing and forming impact including the use of interactive technologies in the academic process.

Interactive training is the process when the learner is involved in the activities. He is enabled to talk, manage, simulate, write, draw and etc. and is not only listener and observer but actively participates in the activities [14, p. 6].

The tendency to introduce interactive methods and technologies into the training is recently observed in Ukraine. That is a characteristic feature of nowadays and one of the important trends in the modernization of domestic education and significant condition for providing the educational requirements.

It should be noted that at present the problems of developing and introducing innovative pedagogical technologies into the university academic process are being investigated both in theoretical and didactical aspects; foreign experience of introducing the innovative pedagogical working outs are actively studied as well.

\section{Analysis of the Latest Researches and Publications}

Principal problems of the educational innovations in modern domestic theory and practice are being studied by: Yu. Babanskyi, M. Bashmakova, I. Bomba, L. Burkova, L. Vashchenko, V. Davydova, L. Danylenko, D. Johnson, P. Drobyazko, O. Dusavytskyi, V. Zhyvodora, O. Kozlova, M. Kryuger, J. Meyers, A. Pidlasyi, N. Pogribna, S. Podmazin, O. Pometun, O. Popova, I. Prygozhyn, H. Selevko, K. Ushakova, N. Fedorova, A. Khutorskoy, N. Yusufbekova and others.

Among the foreign scholars who are studying interactive technologies we can name as follows: D. Johnson, J. Dewey, L. Bradford, Joseph Edward Mayer, Carl Rogers, C. Stout, J. Schneider and others.

Mentioned problematics is covered in the researchers of domestic psychologists: L. Burlachuk, I. Vachkov, V. Zakharov, L. Karamushki, S. Maksymenko, L. Petrovska, N. Povyakel, N. Chepeleva, T. Yatsenko and others. 
The problem of introducing the interactive technologies into the academic process and improving the technologies of the future specialists training are investigated by: V. Bezpalko, I. Bohdanov, I. Dychkivska, V. Yevdokymov, I. Prokopenko, M. Klarin, O. Smolyuk; forms and meyhods of active training are researched by P. Shcherban, V. Rybalskyi, O. Verbytskyi; adapting interactive technologies to the practice of adults' training are studied by S. Sysoyev, I. Zhernosek, N. Protasova, V. Slastenin, T. Sorochan and other scholars.

Peculiarities of application of interactive technologies, their forms and methods in the educational process are revealed in the research works by such scholars and educators as L. Asimov, N. Bohomolov, Yu. Yemelyanov, V. Zakharov, Ye. Mykhaylov, V. Platanov, A. Panfilov, L. Petrovska, A. Smolkin, N. Khryashchov and others.

M. Klarin, V. Kremen, L. Pyrozhenko, Ye. Polat, H. Pyatakova, A. Khutorskyi and other scientists pay attention to the development and introduction of interactive educational forms into the process of future specialists' training.

Appearance, development and introduction of interactive methods into the higher education system are specified by the fact that these days modern education faces new tasks: not only to give students the knowledge but to provide formation and development of their cognitive activities and abilities, creative thinking, skills for independent brainwork.

Uprising of those new tasks is also stipulated by rapid development of information technologies. It should be stressed that earlier the skills and abilities gained during the higher educational training could be used for a long period of time or even during the whole period of working activities but nowadays in the century of information technologies it is necessary to upgrade and improve them constantly.

The same concerns the culturological education and is supported in the research works by $\mathrm{M}$. Levenets who states that "culturological education in the Ukrainian universities today goes through complicated situation connected with the formation of new strategies and models of development of education in general and culturological education in particular and the last is based on the principles of globalization and regionalization, integration and diversity of educational structures, unification of directions and specialties of professionals' training, innovativeness of educational techniques" [5]. 
The analysis of scientific-methodical literature, studying the experience and considering our own practical experience enable us to make a conclusion that some aspects of the problem under investigation have been studied but the place and role of interactive technologies in the educational system of the universities of culture and arts are not investigated and revealed enough in up-to-date researches.

Thus, the actuality of the given problem, its insufficient development in the domestic pedagogical science, necessity to overcome existing contradictions and requirements to be introduced into the educational process of universities of culture and arts stipulated our research.

Object of our research - to introduce interactive educational technologies in the professional training process of future specialists for the sphere of cultural-and-leisure activities in the university culture and arts.

Subject of our research is the contests of interactive training forms and their impact on improving the students' motivation for creative and professional development.

Aim of our Research: to prove theoretically, develop, introduce and examine effectiveness of implementation the interactive training methods into the educational process of the universities of culture and arts.

The aim of our research is stipulated by defining and solving the following tasks:

- to analyze scientific works on the problem under survey and generalize theoretical principles of using the interactive technologies in the system of higher education;

- to specify the key notions ("innovative educational technologies", "interactive technologies", "active training", "interactive training", "specialist", "cultural-and-leisure sphere").

- to analyze the state and problems of introduction the interactive methods into the educational process of the higher educational institution;

- to specify the effectiveness of the professional development of the future specialists of the cultural-and-leisure sphere by means of introduction the interactive methods and technologies into the academic process.

\section{Survey methodology}

In accordance with the defined tasks of our research the following methods have been applied: the analysis of philosophic, culturological, psychological, pedagogical literature on the problem under study; gener- 
alization of the theoretical data, comparison, systematization, classification, contrast).

Chosen direction of the research is in correspondence with the scientific-research theme of the Department of Culturology of Separate Division "Mykolaiv Branch of Kyiv National University of Culture and Arts": "Development of Professional Competence of Future Specialists of Cultural-and-Leisure Sphere in the Terms of European Integration".

\section{Findings}

Introduction of interactive technologies into the academic process in the universities of culture and arts should be performed minding different types of pedagogical innovations which could result in positive changes of the traditional pedagogical process. They are basing on the new achievements of the pedagogical science and shall ensure higher level of the professional training of future specialists of cultural-and-leisure sphere.

Studying the experience as for introducing innovative pedagogical technologies into the system of higher education in Ukraine enable us to outline some positive tendencies, namely: raising the diagnostic directions, social-gaming training context, dialogueness, modelling of different professional situations, improving the role of creative personality of the student.

The research works of the modern scholars (N. Balytska, K. Bakhanov, O. Bida, H. Voloshyna, O. Yelnikova, H. Kobernyk, N. Kolomiyets, L. Kondrashova, O. Korotayeva, L. Pyrozhenko, N. Pobirchenko, O. Pometun, H. Samokhina, T. Serdyuk, M. Skrypnyk, N. Suvorova, G. Shevchenko, P. Shevchuk and others) prove that among existing problems of the higher education one of the most important is to create such training conditions those could give a student the opportunity to research independently and deeply general problems of culture expressed in the contests of the educational process and develop themselves in professional and creative way.

O. Shapran proves that the innovative pedagogical technology combines well-organized totality of actions, operations and procedures which ensure the creation and gradual introduction of different types of pedagogical innovations positively affected traditional pedagogical process, modernize and transform it [16, p. 23].

Term "interactive training" is quite new and it was introduced in 1975 by the German scholar G. Fritz who defined the purpose of the interactive process which foresees the changes and improving the models of participants' 
behavior. Analyzing partner's reactions and the reactions of his own, the participant shall change the model of his behavior and consciously takes it over that enables to talk about interactive methods as the process of interactive training [6, p. 46].

Term "interactive" is a compound word which consists of two words "inter" (that means "mutual") and "act" (that means "to have an effect"). Interactive method is a type of interaction by means of conversation, dialogue [13, p. 53].

Nowadays, "interactive training", "interactive training technologies" are mostly studied in terms of partner interaction, mutual cognitive process, constructive training dialogue in the frameworks of the systems "students-lecturer", "student-educational environment of the higher educational institution" [10, p. 23].

Interactive training is a specific form of cognitive activities organization with its specified goals. One of those is to make comfortable conditions for studies when a student feels himself successful, improve his intellectual level and those make training process much more effective [2].

Basic principle of interaction is many-sided communication characterized by the absence of polarity and minimal concentration on the lecturer's point of view [3].

Interactive training is based on the principle of direct participation of everyone and that obliges the lecturer to make a student the object of teaching-and-educational process who shall search the ways and means to solve the problem out.

The usage of interactive forms and methods allow forming the knowledge and skills involving students to active educational-cognitive activities.

Psychologists (R. Bybrykh, V. Znakov, L. Karamushka, N. Kolomenskyi, T. Kornylova, Yu. Shvalb and others) mark that the formation of knowledge is more effective when the activity is higher and that results in better understanding, memorizing, storing and renewing new information but make the skill to get new knowledge and skills practically.

It should be noted that in a number of researches (N. Anikeyeva, I. Abramova, L. Borysova, A. Verbytskyi, I. Ivanov, V. Platov, V. Podinovskyi, V. Rybalskyi, A. Smolkin, I. Syroyezhyn, S. Shmakov and others) it is firmly proved that the majority of effective changes in orientations, motivations and behavior of adults are easier to be done in groups i.e. in the process of group interactive training. 
Scholars and scientists proved and supported that innovative interactive education stimulates cognitive activities and encourages the formation certain competences with the students: to obtain the stages of educational activities; to develop critical thinking; to advance their self-confidence; to development self-sufficiency; to firm positive "Self-concept"; to develop creativity, managerial and communicative abilities; to form correspondent life and professional competences; to make the atmosphere of cooperation and active interaction; to rise the successfulness [10].

Mentioned above enables us to make a conclusion that interactive training methods comprise interconnected mutual activities of students and a lecturer when all participants of the educational process interact with each other, exchange the information, solve the problems out together, model situations, dip into the atmosphere of cooperation with joint settling down the problems.

As interactive training foresees the demonstration of the pedagogical process participants' activity so active methods applied in it are considered to be an obligatory constituent of interactive technologies.

It should be noted that the forms of interconnection between a lecturer and students in the teaching-and-educational process are based on three groups of methods: passive, active and interactive training.

Passive method is a type of lecturer-student interaction when the lecturer is a principle figure at the class and the students are passive listeners.

In contrast to active training methods those are based on one-sided communication (it is initiated and encouraged by the lecturer), interactive methods conceptually change the scheme of communication in the educational process [7].

Active training assumes that when analyzing his own reactions and partner's reactions, the participant of the educational process shall remodel his behavior and consciously adopt it.

Considering students' activity we should accept that intensive activities and practical training in the educational process and knowledge and skills formation, ability to use them in certain situations. Training activity is a basic condition of conscious learning [14, p. 173].

Interactive methods are the form of training when the students and a lecturer are involved in the conversation and dialogue between each other. That is a kind of cooperation, mutual training: lecturer - student, student students. Herewith, a lecturer and a student are equal and identical subject of the training process. 
It should be stressed that interactive cooperation comprises the prepotency of one participant of the educational process over the other, one opinion over the other.

When the students involved in communication they are learning how to find common language with the others, be democratic, tolerant, to think critically, and to make justified decisions.

Psychological-and-pedagogical provisions allow defining certain educational demands which are to put into effect the interactive methods.

Firstly, language skills' training should be done in the context of students' actual communication with each other.

Secondly, communication training should be included into other activity as its integral part (we mean professional and scientific-educational activities).

Thirdly, the development of language abilities should be performed in the conditions of solving communicative problem-oriented tasks.

To realize students' training in group shall allow the following conditions:

- general goal;

- individual responsibility and levels of possible success;

- interdependence of the group members;

- mutual educational-cognitive and creative activities of the students in group;

- every student's contribution into solving the class assignment;

- general assessment of the group work that includes the estimation of the method of the activity and final output.

Actual problem in modern pedagogical science is seen the problem of interactive training methods' classification. It should be noted that there is no full classification at present. We can suppose that this is connected with the lack of distinct differentiation between active and interactive training methods; the same methods are found as active and interactive ones.

O. Golubkova classifies interactive training methods basing on their communicative functions and divides them into three groups:

- debating methods (conversation, group discussion, developing and analysis of true to life situations);

- game methods (didactic and creative games including business, role, managerial and counter games);

- psychological group of interactive methods психологічна (sensitive and communicative training, empathy) [3, p. 16]. 
Subjective position of the educational process participants is realized basing on the following factors:

- dialogic interaction that foresees, first of all, principal equality of the sides as for understanding the facts, assessment, relations, explaining each other's value-based and ideological views, open atmosphere of interaction, participants' readiness to make conversations, continuous professional and personal attitude of learners;

- subjective activity which is a condition of subjective attitude, the characteristic feature defining success of any activity;

- creative educational environment which foresees the advanced education structure development, its contents and educational technology, ensuring the conditions of emotional-value-oriented study of the given materials $[15$, p. 9].

We should state the features of interactive class which can be found in the peculiarities of the educational process subjects' interaction, in the contents and structure and suppose the following forms:

- physical - participants can change their working places, move free in the classroom, change their seats, communicate, write, listen;

- social - participants interact actively with others, put questions, give answers, exchange the opinions;

- cognitive - participants independently solve the problems, make amendments, give talks and make presentations, gain their own experience.

In accordance with our survey we shall consider interactive training as gaining certain experience during academic process which is characterized by high level of students' activity, quite long duration of the academic activities, their independent creative work, advanced level of motivation and emotiveness, constant interaction the group of students and the lecturer.

With the help of interactive technologies the students are enabled to:

- analyze educational information, study educational material in creative way that makes the process of gaining knowledge more effective and comprehensible;

- study how to form their point of view and express it in understandable way, to give reasons and debate;

- study to listen to other people and respect their alternative opinions;

- model different social situations, enrich their own social experience by means of being involved into various true to life situations and their modelling; 
- study how to build up the relationships inside the group, avoid conflict situations, settle them down, find compromises, be ready for dialogue and consensus;

- develop the skills for project activity, independent work, performing creative activities.

The following principles of interactive training are allocated:

Principle of activity. To reach defined goals every student has to take an active part in the process of communication and interact with others in active way.

Principle of open feedback includes suggesting by one student or all students' opinions, ideas or objections as for given tasks. Due to active use of feedback principle the members of the group can learn how other people percept their manner of communication, way of thinking or peculiarities of behavior.

Principle of experiment is students' active search of new ideas and ways of solving suggested tasks. This principle is very important as it might be a sample of the strategy applied for the real life and be an impact for the development of creativity and initiative of the student's personality.

Principle of trust in the communication is directed on the special organization of the educational space for the group during the class and is based on the refusal from classically equipped classroom but the students and a lecturer are sitting in circle facing to each other in order to change the students' stereotypic orientation and traditional viewpoint as it is necessary to deliver and arrange interactive classes and a lecturer's role during that kind of classes.

Principle of equality of the positions means that the lecturer does not aim to force his ideas and thoughts on students but acts together and on equal terms with them, in turn, every student can perform the role of organizer, leader.

Mentioned above lets us make a conclusion that the educational process is built up basing on active group and individual activity as for gaining certain experience.

When using that kind of approach there is an emphasis on independent learning of the theoretical material, discussions and debates in groups, analysis of certain situations (case method), business games, developing of creative individual and team projects etc.

Everything aforesaid enables us to outline the following specific features of interactive training comparing with classical academic education: 
- preceptive activation of thinking i.e. to build up such kind of educational situation when a student has to be active in spite of his wish;

- involving the students into the educational process i.e. their activity should be long-term but not short-term or even episodic;

- the period of activity of every member of the students' group has to coincide with the period of lecturer's activity i.e. students' activity must have the same duration as the lecture's one;

- independent creative solutions made by the group, micro groups during individual tasks performing;

- higher level of students' motivation and emotiveness;

- constant interaction between the group and the lecturer with the help of direct and indirect connections [8, p. 39].

We should emphasize that interactive training is essentially differs from traditional one, stimulates formation of deep motivation, gives possibility for intellectual and creative self-development, revealing the initiative and develops communicative skills. Thus, the use of the given type of education is to be an integral part of the process of training of the future specialists for cultural-leisure sphere in the universities of culture and arts.

We are to consider the use of the interactive training methods minding the specific character of training of future specialists for cultural-leisure sphere and specificity of educational subjects in the Separate Division "Mykolaiv Branch of Kyiv National University of Culture and Arts" as exemplified by teaching the following subjects: "Animation-gaming leisure technologies", "Organization of animation activities", "Organization of leisure for tourism industry", "Recreation management", "Entertainment and leisure industry" for culturology students: leisure activity managers, event-managers.

Authors have developed and put into practice the syllabi in such subjects as "Animation-gaming leisure technologies", "Organization of animation activities", "Organization of leisure for tourism industry", "Recreation management", "Entertainment and leisure industry". When teaching of those the meaningful attention is given to making certain psychological-and-pedagogical conditions in order to use interactive training methods in an effective way.

Lecturers' serious preparation work has been done before teaching those subjects. They selected certain interactive and animation-gaming methods, creative exercises and tasks influencing the value of the proposed syllabi and directed on solving the specific tasks necessary for further professional 


\section{Peculiarities of the usage of interactive technologies in the process of...}

activities of the workers of cultural-leisure sphere. Mistakes and negative consequences in further professional activities have been analyzed. It should be stressed that they can result in inadequate formation or lack of certain skills with the future specialists those might have been formed in the process of studying mentioned above academic subjects.

When teaching future professionals of cultural-leisure sphere, lecturers use professionally directed interactive methods, namely: didactic, business and training games, trainings, debates, brainstorming, ideas public defense, adaptation for the stage and staging methods, market and auction of ideas, intellectual warming-ups, pair share, micro group work, "aquarium" method, "Karusel" (merry-go-round), "SOHP" method (self-organized educational space), discussing problems in the general circle, "hot microphone", "case" method, problem solving method, "tree of decisions" method, animation games, "role playing" method, "position taking" method, "position changing" method, "uninterrupted scale of thoughts" method, "unbroken chain" method, discussions and debates.

During the classes in mentioned above academic subjects great attention is paid to the following methods: problem-oriented discussion (when the participants change information and ideas in an active way in order to search and solve given problem); analysis of certain situations (considering by the team a true to life situation which needs solving of one or several problems with a number of possible answers); situation-role games (participants play different roles modelling certain true to life situation from the sphere of culture and leisure); creative presentations (making public presentations of creative reports devoted to performed tasks); work in small groups (a group of 4-5 students is given a task and they are responsible for its fulfilment together as a whole team; duties among the members of the team are divided by themselves independently); individual tasks (when students are given an opportunity to solve a certain problem or task independently).

The authors of the syllabi used to try avoiding any pressure on the students from the lecturer's side and ignoring lecturers' thoughts and offers. It should be said that there is an indisputable regularity: the more a person is imposed something ununderstandable and incomprehensible the more inner opposition that arouses and might result in conflict, ignoring or formal attitude to the process of studying.

And vice versa, the more concrete and understandable is an offer, the more forces and energy have been given when making common decision, 
the more is the output and, in this case, the student tries harder when studying.

During the process of teaching the lecturers are constant searching more effective methods. In the practice of teaching such subjects as "Animation-gaming leisure technologies", "Organization of animation activities", "Organization of leisure for tourism industry", "Recreation management", "Entertainment and leisure industry", one of the key methods is training game method which is highly effective as for encouraging motivation and giving students space for practical use of the given professional knowledge and that foresees maximum closing to the true to life situations both in everyday ones and professional sphere. Conditional problem situation is a basic aspect of the game and is developing during the class as a separate animation-gaming plot. As a rule, it is based on the real professional problem and its solving requires from the students certain professional competences.

To play the game and make the game plot it is necessary to have enough choice of parts to be divided between all participants of the class. This interactive method covers the opportunities to solve the problems which do not have a single decision and encourages future specialists to search original decisions and ways to draw back unpredictable situations.

Moreover, it is important to ensure to feel free choosing tasks and training parts minding students' individual abilities and opportunities. The students must be active and act in non-standard way and exercise the situation of success at every stage of work which enables to form the professional communication skills, an ability to listen to the counterpart, argue and defend his own point of view, develop creative personality of every participant of the game.

Gaming method foresees making subject and social contests of future professional activity, modelling relationships, which it is characterized by, professional problems, real contradictions and hardships those exist in typical professional problem situations [12, p. 126].

In the process of game there is occurring a true to life communicative situation among the students; they are working out certain skills, revealing certain thinking processes and personal characteristics of the future specialists. With the help of training games, the formation of an entire view of the professional activities and its dynamics, development of problem-professional and social experience, theoretical and practical thinking are happening in order to ensure the realization of the correspondence principle of 


\section{Peculiarities of the usage of interactive technologies in the process of...}

future cultural-leisure sphere professionals' training to the demands of the modern society.

The application of gaming methods helps not only to arise students' interest but to model various professional situations in the educational process. It becomes a kind of an effective "communicative simulator" and makes a favorable emotional atmosphere at the classes and, moreover, this method is used to role-play team playing situations and assist to develop memory, critical thinking and communicative skills with the students.

During the game there arouses an opportunity to communicate in easy and comfortable way. So, students' demand in real professional communication is realized in certain format during the classes when the lecturers model and help students to experience those true to future professional life situations.

The usage of interactive method of games in the educational process encourages an effective adoption by the students the professional experience and managing the process of professionalization. It should be noted that professional activities modelling which is occurring by means of game and game modelling and gives students an opportunity to develop professional behavior skills and make possibilities to exercise those professional skills.

When those methods are used during the practical classes in "Animation-gaming leisure technologies", "Organization of animation activities", "Organization of leisure for tourism industry", "Recreation management", "Entertainment and leisure industry", that helps to organize dialogue communication among the students which can result in mutual understanding, interaction and mutual solving of the given educational tasks.

Such kind of interactive classes include both domination of one speaker and domination of one view over the others. With the help of dialogues students study to think critically, solve out complicated problems basing on the thorough analysis of the circumstances and certain information, assess alternative ideas, make firm decisions, take part in discussions, communicate with other people.

To reach mentioned above at the practical classes, individual, paired and team work is organized, the students are offered to role-play, make game projects, give opportunities to work with the documents and other sources of information, use different creative tasks in order to work over further training creative projects and then to show them in front of the audience.

Considering the use of innovative gaming technologies, it should be noted that the advantages of those methods are as follows: 
- communication by means of game which make students closer to true to life conditions;

- professional skills' training by the members of the game;

- making higher the level of obtaining the professional skills and peculiarities of thinking processes;

- development and improvement of students' personal qualities.

Key criteria of such given to students interactive training game models are the following: possibility of informal discussion, fluent material presentation, increase of students' initiative, enforcing the motivation, presence of team tasks which require team efforts to be solved.

Professional training of the specialists for cultural-leisure sphere is characterized by obtaining the system of certain knowledge, formation of professionally important skills and qualities of the future specialists and that becomes possible combining both traditional and innovative methods of teaching.

The realization of certain principles is a meaningful condition for such kind of training. In the context of our survey we have outlined the following principles:

- connection of theory and practice (students must know how and have opportunities to adapt given knowledge in their practical activities);

- bringing up character of training (the culture of creative work is trained);

- systematicity and subsequence (keeping in mind the regularities of teaching the practical subjects); the principle of synergy of methods, devices, means and forms.

The use of various forms and methods of interactive training enables teachers to adapt new pedagogical ethics of communication with the students (principle of creative cooperation), to use the dialogue as a dominant form of communication which helps to form with students the abilities to exchange their thoughts and ideas freely, to model life situations and to be oriented to creative development.

The last is supported by psychological and pedagogical studies by N. Pobichenko, H. Kibernyk, H. Selevako, O. Pirozhenko in those researches it is scientifically stipulated that team educational activities enable to activate and get results of the training, to teach independence, to give, prove and defend the point of view.

But the investigations by N. Suvorova, V. Lozova, L. Zaretska, H. Trotsko, M. Smetanskyi convincingly prove that interactive technologies 
can change the scheme of communication in the education process in the principle way. They are oriented to the realization of cognitive processes and demands of the personality and the special attention is paid to the organization of the effective communication process in order to make the participants of that interaction process more mobile, more open and more active.

The analysis of the existing experience when teaching such educational subjects as "Animation-gaming leisure technologies", "Organization of animation activities", "Organization of leisure for tourism industry", "Recreation management", "Entertainment and leisure industry" justifies that the use of interactive methods at the classes encourages the improvement of the personal sphere of each student, reduces the level of aggressiveness and strife, develops professional competence and study motivation, increases the process of gaining and making firmer theoretical knowledge by means of practical skills and abilities.

Everything mentioned above allows us to state that specific features of the interactive classes in the system of higher education in the universities of culture and arts are to:

- follow the team working principles; orientation to assist students in the process of their self-development not only with the help of a lecturer who delivers the classes but with the other students of the group;

- define the space organization (interactive classes are held in the comfortable isolated classroom where the students have an opportunity not only to sit in a circle but to move freely; the accent is made on the mutual relations between the students who are working in the situation "here and now";

- use active team working methods (group debates, brainstorming, synectic sessions, focus-groups, situation role and business games, psychological exercises, game projecting);

- arouse subjective feelings and emotions of every student in the group; verbalize reflexion; make the atmosphere of openness and free communication; make the climate of psychological safety.

\section{Conclusions}

Thus, interactive training methods are considered to be organic and essential addition to the classical training methods. They encourage the activation of thinking process, students' knowledge and skills in order to achieve good results in the educational activities and to perform operative feedback. To organize educational process, where traditional and inter- 
active methods are combined, assists making the training process for the future specialists of cultural-leisure sphere more effective.

The introduction of interactive methods into the contests of professional training of the future specialists of the cultural-leisure sphere enables to solve different social, psychological and pedagogical problems and by means of their additional possibilities to form students' readiness of settling down various problems in the future professional activities independently.

At the same time studying peculiarities and specific features of using interactive technologies in the system of education of the universities of culture and arts helps to optimize and improve educational process.

Implementation of the interactive technologies into the educational process of the higher educational institution of the universities of culture and arts assists to make favorable reflective space with opportunities for independent and conscious search of the future professional activities contests, self-analysis and professional consciousness activation, more effective searching of information and forecasting further professional development, searching the ways of own professional realization and improving the competitiveness in the employment market. In the conditions of such kind of classes, students can perform certain roles those make them able to understand better the other person's feelings and study how to model different strategies of future professional behavior.

Our survey does not cover all aspects of the given problem, to the full extent, and requires further scientifically based investigations and presentation of the gained results that is supposed to be made in the further scientific publications.

\section{References:}

1. Lisovyi V.M., Markovskyi V.D. (2012) Vykorystannya novitnikh tekhnologiy dlya osobystisnoyi pidgotovky studentiv KHMU [Use of Innovative Technologies for Personal Training of the Students of KhNMU]. Materials of AllUkrainian Educational Scientific Conference. Ternopil, pp. 45-47.

2. Verbitskiy A.A. (1993) Aktivnoye obuchenie v vysshey shkole: kontekstnyy analiz [Active training in the Higher School: context analysis]. Moscow. (in Russian)

3. Holubtsova I.A. (2007) Vprovadzhennya interaktyvnykh tekhnologiy [Introduction of Interactive Technologies]. Organization of Educational-Training Process, no, 9, pp. 159-174.

4. Zmeyev S.I. (2007) Androgogika: osnovy teorii i tekhnologii obucheniya vzroslykh [Androgogics: Groundings of Theory and Technology of Adults' Education]. Moscow: PER SE. (in Russian) 


\section{Peculiarities of the usage of interactive technologies in the process of...}

5. Levenets M.V. Modelyuvannya kulturologichnoi osvity v suchasnykh vyshchykh navchalnykh zakladakh [Culturological Education Modelling in Higher Educational Institutions]. Retrieved from: // http: nbuv. Gov.ua

6. Livanova E.A., Voloshyna A.G., Pleshakov V.A., Soboleva A.N., Telegina I.O. ИгIgra v treyninge. Vozmozhnosti igrovogo vzaimodeystviya [Game in the Training. Opportunities for Game Interaction]. St.Petersburg: Piter (in Russian)

7. Lutsyk H.H. (2008) Osoblyvosti zastosuvannya interaktyvnykh tekhnologiy navchannya $\mathrm{v}$ pedagogichnykh koledzhakh [Peculiarities of Using Training Interactive Technologies in the Pedagogical Colleges]. Novi tekhnologii navchannya u pepedagogichnykh koledzhakh. Scientific Journal, no. 53, pp. 46.

8. Arutyunov Yu.S., Birshteyn M.M., Burkov V.N. (1989) Metodicheskiye ukazaniya po klassifikatsii metodov aktivnogo obucheniya [Methodical Aids as for Active Teaching Methods Classification]. Kyiv. (in Russian)

9. Moroz L.I. (2007) Profesiyno-psykhologichnyi treyning u stanovlenni osobystosti fakhivtsya [Professional-Psychological Training during the Formation of Professional Personality]. Ivanofrankivsk: Nadvirnyanska drukarnya. (in Ukrainian)

10. Padalka O.S., Nisimchuk A.S., Smolyuk I.O., Shpak O.T. (1995) Pedagogichni technologii [Pedagogical Technologies]. Kyiv: Ukrainian Encyclopedia. (in Ukrainian)

11. Pisotska L.S. (2013) Vykorystannya interaktyvnykh metodiv navchannya $\mathrm{v}$ konteksti systemnogo pidkhodu [Use of Interactive Methods of Education in the System Approach Context]. Pedagogical Discourse: Collection of Scientific Articles. Khmelnytskyi: KhGPA, issue 14, pp. 360-363.

12. Pidkasystyi P.I. (1996) Tekhnologiya igry v obuchenii I razvitii [Game Technology in Teaching and Development]. Moscow: Pospedagenstvo. (in Russian)

13. Pometun O.I. (2004) Suchasnyy urok. Interaktyvni tekhnologii navchannya [Modern Lesson: Interactive Teaching technologies].Kyiv: A.S.K. (in Ukrainian)

14. Abulkhamova K.A., Vasina N.V., Lapteva L.G., Slastenina V.A. (1998) Psikhologiya Пi i pedagogika [Psychology and Pedagogics]. Moscow: Sovershenstvo. (in Russian)

15. Pyatakova H.P. (2002) Interaktyvni metodyky ta spetsyfika zastosuvannya ikh zastosuvannya $\mathrm{u}$ vyshciy shkoli [Interactive methods and specifics of their use in the higher school]. Ternopil. (in Ukrainian)

16. Shapran O.I. (2007) Systema innovatsiynoi pidgotovky maybutnyogo vchytelya $\mathrm{v}$ umovakh navchalno-naukovo-pedagogichnykh kompleksiv [Future Teacher Innovative Training System in the Terms of Educational-ScientificPedagogical Complexes]. Pereyaslav-Khmelnytskyi: S.V. Karpuk Publishing. (in Ukrainian) 